\title{
Datum Geodetik Batas Maritim Indonesia - Singapura: Status dan Permasalahannya
}

\author{
Hasanuddin Z. Abidin ${ }^{1)}$, K. J. Villanueva ${ }^{\text {1) }}$, Sobar Sutisna ${ }^{2)}$ \& T. Padmasari ${ }^{2)}$ \\ ${ }^{1)}$ Departemen Teknik Geodesi, Institut Teknologi Bandung, \\ Jl. Ganesha 10, Bandung 40132, E-mail: hzabidin@gd.itb.ac.id \\ ${ }^{2)}$ Pusat Pemetaan Batas Wilayah, Badan Koordinasi Survei dan Pemetaan Nasional \\ (BAKOSURTANAL), Jl. Raya Jakarta-Bogor Km.46, Cibinong, Bogor
}

\begin{abstract}
Abstrak. Batas maritim antara Indonesia dengan Singapura di selat Singapura sudah diatur dengan Perjanjian 1973 tentang Batas Laut Teritorial antara kedua negara. Pada naskah perjanjian ini tidak dicantumkan secara spesifik datum geodetik dari koordinat keenam titik batas maritim antara Indonesia dan Singapura. Makalah ini akan mengkaji empat datum alternatif untuk koordinat titik batas tersebut, yaitu KERTAU48, KERTAU68, GENUK dan SOUTH ASIA, serta dampaknya terhadap koordinat dan lokasi dari titik-titik batas. Permasalahan lain yang terkait juga dibahas dan dianalis. Makalah ditutup dengan beberapa kesimpulan dan saran.
\end{abstract}

Kata kunci: Datum; Batas; Maritim; Indonesia; Singapura; KERTAU48; KERTAU68; GENUK; SOUTH ASIA.

\begin{abstract}
Maritime boundary between Indonesia and Singapore in the strait of Singapore has been defined by the territorial sea boundary treaty of 1973.In this treaty, geodetic datum of the geographic coordinates of six boundary points between Indonesia and Singapore are not explicitly stated. This paper investigates the possible datum for these coordinates, namely KERTAU48, KERTAU68, GENUK and SOUTH ASIA, and its impacts on the coordinates and location of boundary points. Related aspects are also discussed. Paper is sum up with some conclusions and recommendations.
\end{abstract}

Keywords: Datum; Boundary; Maritime; Indonesia; Singapore; KERTAU48; KERTAU68; GENUK; SOUTH ASIA.

\section{$1 \quad$ Pendahuluan}

Indonesia punya batas maritim dengan negara dengan 10 negara tetangga yaitu Australia, Timor Leste, Papua New Guinea (PNG), Palau, Filipina, Vietnam, Thailand, Malaysia, Singapura dan India, yang panjangnya mencapai ribuan $\mathrm{km}$. Proses penataan batas maritim dengan negara-negara tetangga tersebut sudah dilaksanakan sejak lama oleh Pemerintah Indonesia, meskipun belum tuntas semuanya untuk seluruh zona maritim yang terkait tersebut. Status

Makalah diterima redaksi tanggal 2 Maret 2005, revisi diterima tanggal 28 Maret 2005. 
perjanjian batas maritim antara Indonesia dengan negara tetangga ditunjukkan pada Tabel 1.

Tabel 1 Status Perjanjian Batas Maritim Indonesia dengan Negara Tetangga. [The Geographer, 1990; Forbes, 1995].

\begin{tabular}{|c|c|c|c|}
\hline \multirow{2}{*}{$\begin{array}{l}\text { Dengan } \\
\text { Negara }\end{array}$} & \multirow{2}{*}{ Jenis Batas } & \multicolumn{2}{|c|}{ Tanggal } \\
\hline & & Penandatangan & Ratifikasi \\
\hline Singapura & Territorial Sea & $25-05-73$ & $29-08-74$ \\
\hline \multirow{3}{*}{ Malaysia } & Territorial Sea & $17-03-70$ & $08-10-71$ \\
\hline & Continental Shelf (3) & $27-10-69$ & $07-11-69$ \\
\hline & Continental Shelf (+ Thailand) & $21-12-71$ & $16-07-73$ \\
\hline Vietnam & Continental Shelf & $26-06-03$ & belum \\
\hline Filipina & Continental Shelf & belum & belum \\
\hline \multirow{2}{*}{ Papua Nugini } & Territorial Sea (2) & $12-02-73$ & $26-11-74$ \\
\hline & Continental Shelf & $13-12-80$ & $10-07-82$ \\
\hline \multirow{4}{*}{ Australia } & $\begin{array}{l}\text { Continental Shelf } \\
\text { (Seabed) (2) }\end{array}$ & $\begin{array}{l}18-05-71 \\
09-10-72\end{array}$ & $08-11-73$ \\
\hline & Fishing Zone & $29-10-81$ & $01-02-82$ \\
\hline & $\begin{array}{l}\text { Continental Shelf } \\
\text { (Zone of Cooperation) }\end{array}$ & $11-12-89$ & 09-02-91 \\
\hline & ZEE & $14-03-97$ & belum \\
\hline \multirow{2}{*}{ Timor Leste } & Territorial Sea & belum & belum \\
\hline & ZEE dan Continental Shelf & belum & belum \\
\hline \multirow{3}{*}{ India } & Continental Shelf & $08-08-74$ & $17-12-74$ \\
\hline & Continental Shelf/ZEE & $14-01-77$ & $15-08-77$ \\
\hline & Continental Shelf (+ Thailand) & $22-06-78$ & $02-03-79$ \\
\hline \multirow{3}{*}{ Thailand } & Continental Shelf (2) & $\begin{array}{l}17-12-71 \\
11-12-75\end{array}$ & $\begin{array}{l}16-07-73 \\
18-02-78\end{array}$ \\
\hline & Continental Shelf (+ Malaysia) & $21-12-71$ & $16-07-73$ \\
\hline & Continental Shelf (+ India) & $22-06-78$ & $02-03-79$ \\
\hline Palau & ZEE dan Continental Shelf & belum & belum \\
\hline
\end{tabular}

Garis batas antara Indonesia dan negara-negara tersebut untuk setiap zona maritim yang sudah ada, biasanya akan diberikan berupa daftar koordinat geodetik (lintang,bujur). Pada beberapa perjanjian ini, koordinat titik-titik batas tersebut umumnya tidak jelas datum geodetik (sistem referensi koordinat) nya, meskipun pada perjanjian ini biasanya juga dinyatakan penetapan tentang datum geodetik yang melandasi koordinat titik-titik batas tersebut perlu disepakati oleh kedua negara yang berbatasan. Ketidakjelasan tentang datum geodetik dari titiktitik batas maritim Indonesia dengan negara-negara tetangga ini perlu secepatnya dikaji dan dievaluasi sebelum timbul permasalahan kelak. Setidaknya dalam hal ini pihak Indonesia perlu melakukan kajian awal untuk nantinya dapat menjadi bahan masukan bagi tim perunding batas RI di level tertinggi. 
Makalah ini akan menjelaskan status dan permasalahan dari datum geodetik batas maritim antara Indonesia dengan Singapura di selat Singapura yang sudah diatur dengan Perjanjian 1973 tentang Batas Laut Teritorial antara Indonesia dan Singapura.

\section{Titik Batas Laut Teritorial RI-Singapura}

Batas maritim antara Indonesia dengan Singapura di selat Singapura sudah diatur dengan Perjanjian 1973 tentang Batas Laut Teritorial antara Indonesia dan Singapura. Berdasarkan artikel 1 ayat 1 dari Perjanjian tersebut garis batas teritorial antara Indonesia dan Singapura adalah garis-garis lurus yang menghubungan 6 (enam) buah titik batas yang koordinatnya diberikan pada Tabel 2 berikut. Dari enam titik ini, tiga titik ditentukan berdasarkan prinsip sama-jarak (equidistant principle) dan tiga titik ditentukan berdasarkan kesepakatan (negotiated positions). Lokasi dan konfigurasi dari keenam titik batas laut teritorial ini dapat dilihat pada Gambar 1.

Tabel 2 Koordinat geodetik titik-titik batas teritorial Indonesia - Singapura. [The Geographer, 1974].

\begin{tabular}{|c|c|c|}
\hline Titik Batas & Lintang (Utara) & Bujur (Timur) \\
\hline 1 & $1^{\circ} 10^{\prime} 46^{\prime \prime} .0$ & $103^{\circ} 40^{\prime} 14^{\prime \prime} .6$ \\
2 & $1^{\circ} 07^{\prime} 499^{\prime \prime} .3$ & $103^{\circ} 44^{\prime} 26^{\prime \prime} .5$ \\
3 & $1^{\circ} 10^{\prime} 17^{\prime} .2$ & $103^{\circ} 48^{\prime} 18^{\prime \prime} .0$ \\
4 & $1^{\circ} 11^{\prime} 45^{\prime \prime} .5$ & $103^{\circ} 51^{\prime} 35^{\prime \prime} .4$ \\
5 & $1^{\circ} 12^{\prime} 26^{\prime \prime} .1$ & $103^{\circ} 52^{\prime} 50^{\prime \prime} .7$ \\
6 & $1^{\circ} 16^{\prime} 10^{\prime \prime} .2$ & $104^{\circ} 02^{\prime} 00^{\prime \prime} .0$ \\
\hline
\end{tabular}

Selanjutnya pada Artikel 1 ayat 2 dari isi perjanjian dinyatakan bahwa koordinat titik-titik batas tersebut adalah koordinat geografis, dan garis batas yang menghubungkan titik-titik tersebut ditunjukkan pada peta yang dilampirkan sebagai Annexure A dari perjanjian, sebagaimana yang ditunjukkan pada Gambar 1.

Secara umum jarak antar keenam titik batas laut territorial tersebut adalah berkisar antara 1.25 sampai $9.85 \mathrm{~nm}$, dengan kedalaman laut pada lokasinya berkisar antara 12 sampai 20 fathoms (lihat Tabel 3).

Tabel 3 Kedalaman laut dan jarak titik batas teritorial Indonesia - Singapura (Datum Batu Asa); diadaptasi dari [The Geographer, 1974].

\begin{tabular}{|c|c|c|c|c|c|c|}
\hline Titik Batas & $\mathbf{1}$ & $\mathbf{2}$ & $\mathbf{3}$ & $\mathbf{4}$ & $\mathbf{5}$ & $\mathbf{6}$ \\
\hline $\begin{array}{c}\text { Kedalaman } \\
\text { (fathom = } 1.83 \mathrm{~m})\end{array}$ & 17 & \multirow{2}{*}{13} & 12 & 20 & 25 & 20 \\
\hline Jarak $(\mathrm{nm})$ & \multicolumn{2}{|c|}{4.80} \\
\hline
\end{tabular}


Hasanuddin Z. Abidin

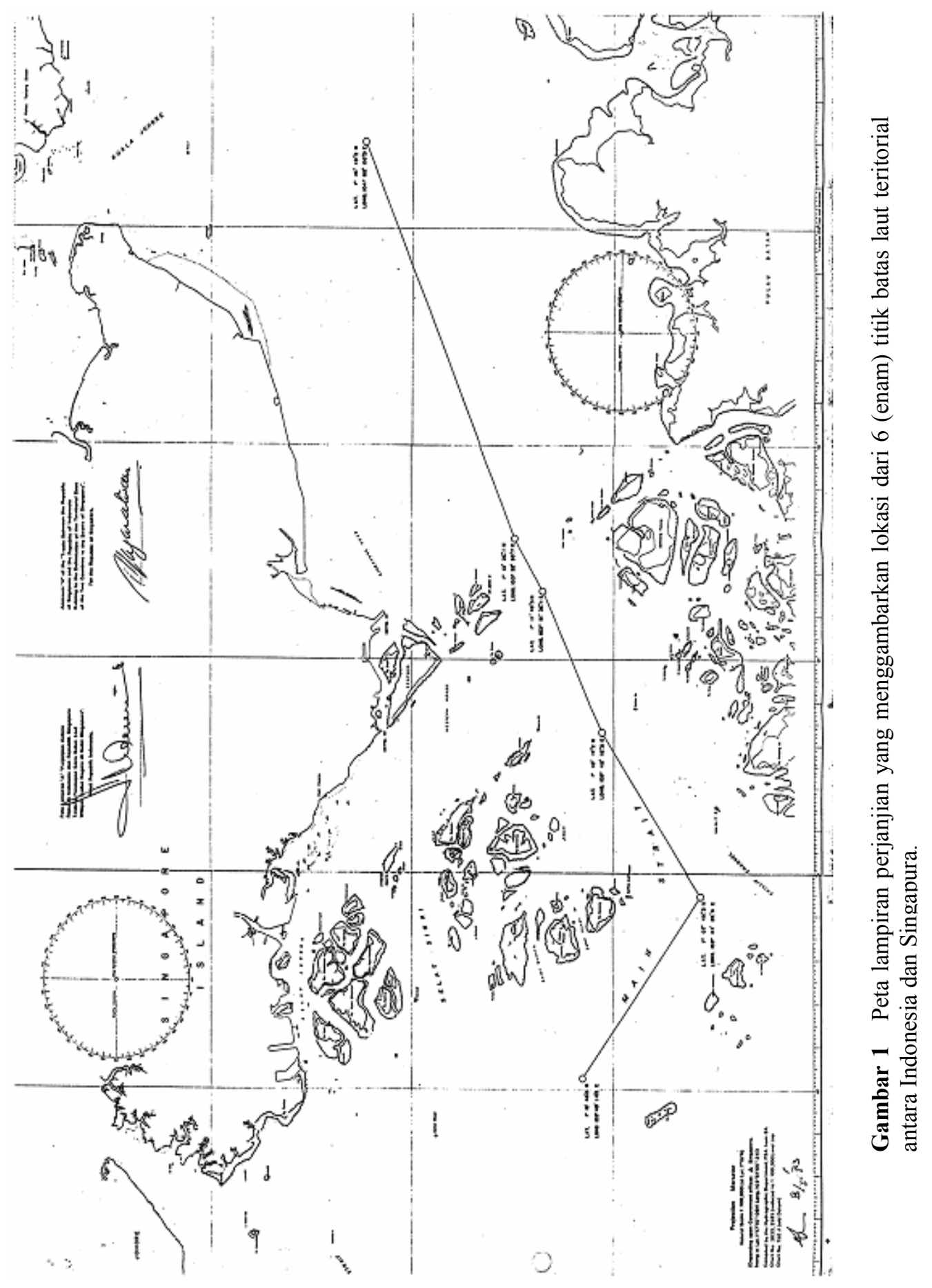


Disamping itu jarak titik-titik batas ke Titik-Titik Dasar yang digunakan pihak Indonesia dan Singapura juga bervariasi, yaitu antara $1.10 \mathrm{~nm}$ sampai $4.65 \mathrm{~nm}$ (lihat Tabel 4). Dari enam titik ini, titik-titik batas 4, 5 dan 6 ditentukan berdasarkan prinsip sama-jarak (equidistant principle) dan titik-titik batas 1,2 dan 3 ditentukan berdasarkan kesepakatan (negotiated positions).

Tabel 4 Jarak titik-titik batas ke titik-titik dasar Indonesia dan Singapura. (Datum Batu Asa); diadaptasi dari [The Geographer, 1974].

\begin{tabular}{|c|l|c|l|l|l|}
\hline $\begin{array}{c}\text { Titik } \\
\text { Batas }\end{array}$ & \multicolumn{1}{|c|}{$\begin{array}{c}\text { Wilayah } \\
\text { Indonesia }\end{array}$} & \multicolumn{2}{|c|}{$\begin{array}{c}\text { Jarak TB dari daratan } \\
\text { (dalam nm) }\end{array}$} & \multicolumn{1}{|c|}{ Wilayah Singapura } \\
\hline 1 & P. Nipah & 1.70 & & 2.80 & P. Sudong \\
\hline 2 & P. Takong Besar & 1.35 & & 1.75 & P. Satumu \\
\hline 3 & Buffalo Rock & 1.10 & & 1.80 & P. Sebarok \\
\hline 4 & Bt. Berhanti & & 1.30 & & P. Sakijang Bendera \\
\hline 5 & Bt. Berhanti & & 1.30 & & $\begin{array}{l}\text { Pulau kecil tak bernama di } \\
\text { sebelah Timur P. Sakijang } \\
\text { Petepah }\end{array}$ \\
\hline 6 & Tg. Sengkuang & & 4.65 & & Tg. Bedok \\
\hline
\end{tabular}

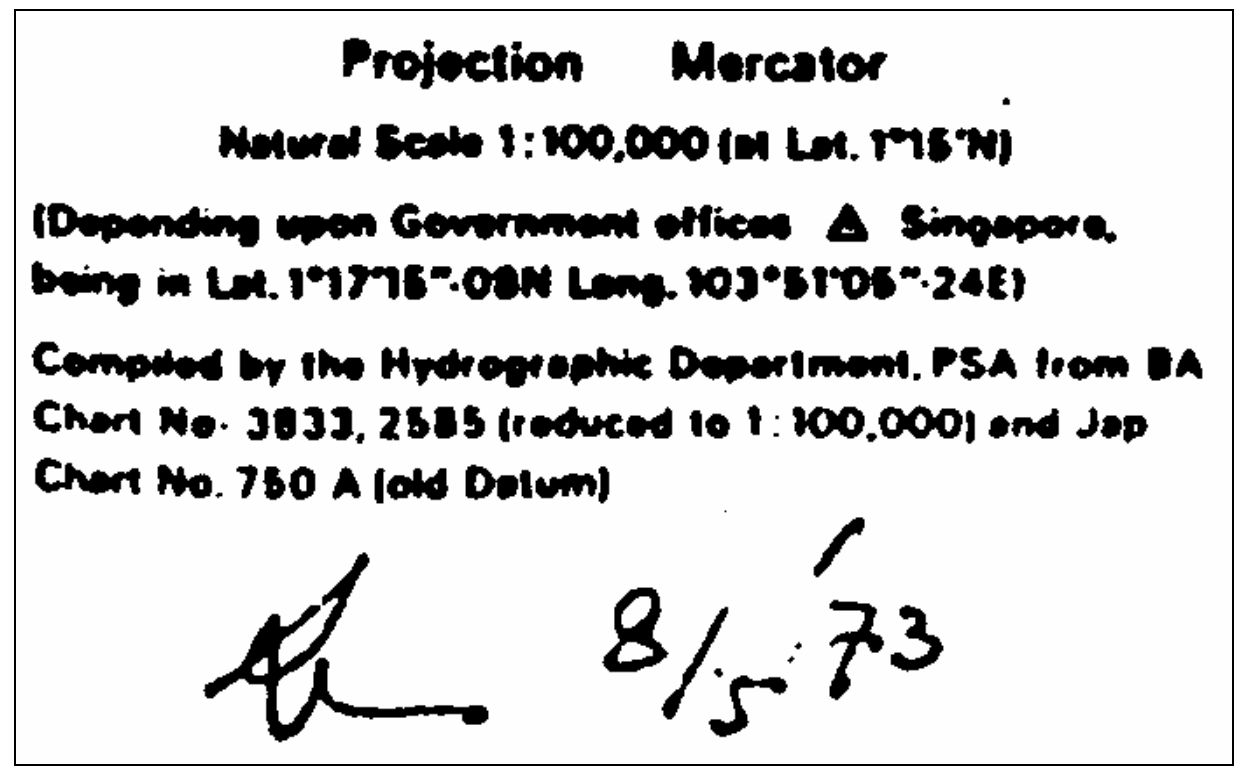

Gambar 2 Legenda dari peta Perjanjian Batas Laut territorial Indonesia Singapura 1973.

Sedangkan pada Artikel 1 ayat 3 dinyatakan bahwa lokasi sebenarnya dari titiktitik batas tersebut di laut akan ditentukan menggunakan metode yang disepakati bersama oleh instansi yang berkompeten dari kedua belah pihak. 
Pada ayat 4 nya dinyatakan bahwa instansi yang berkompeten dari pihak Indonesia berarti Ketua BAKOSURTANAL dan dari pihak Singapura adalah personil yang ditetapkan oleh pemerintah Singapura. Meskipun begitu sampai saat ini setahu penulis, rekonstruksi posisi dari enam titik batas tersebut yang sebenarnya di lapangan belum pernah dilaksanakan.

Pada naskah perjanjian ini tidak dicantumkan secara spesifik datum geodetik dari koordinat keenam titik batas tersebut. Kalau kita lihat legenda dari peta yang merupakan lampiran dari perjanjian tersebut (yaitu Gambar 2) terlihat tidak ada informasi yang eksplisit tentang datum geodetik yang digunakan.

\section{Datum Geodetik Batas Maritim Indonesia dan Singapura}

Seperti telah dinyatakan sebelumnya, dalam perjanjian batas maritim antara Indonesia dan Singapura, datum geodetik dari koordinat titik-titik batas yang diberikan tidak pernah disebutkan secara tegas. Peta yang dilampirkan pada perjanjian batas lebih dimaksudkan untuk menunjukkan lokasi dan konfigurasi dari titik-titik batas dan bukan untuk menginformasikan datum geodetik dari titik-titik batas yang bersangkutan.

Kalau kita memperhatikan waktu penanda tanganan serta kawasan cakupan dari perjanjian batas maritim antara Indonesia dan Singapura, ada beberapa alternatif datum geodetik yang dapat dipertimbangkan untuk koordinat geografis dari titik-titik batas yang dinyatakan dalam perjanjian tersebut. Alternatif tersebut diberikan pada Tabel 5.

Tabel 5 Alternatif Datum Geodetik Batas Maritim Indonesia dan Singapura.

\begin{tabular}{|c|l|l|l|}
\hline Perjanjian Batas & \multicolumn{1}{|c|}{ Kawasan } & Tandatangan & \multicolumn{1}{|c|}{ Datum Geodetik ? } \\
\hline & & & 1. KERTAU48 \\
Laut Teritorial & Selat Singapura & $25-05-73$ & 2. KERTAU68 \\
& & & 3. GN. GENUK \\
& & & 4. SOUTH ASIA \\
\hline
\end{tabular}

Keempat datum geodetik alternatif pada Tabel 5 di atas adalah datum toposentrik yang menggunakan ellipsoid referensi seperti yang diberikan pada Tabel 6.

Tabel 6 Datum dan Ellipsoid referensi yang Digunakan.

\begin{tabular}{|c|c|c|c|}
\hline Datum Geodetik & Ellipsoid Referensi & $\mathbf{a ~ ( m )}$ & $\mathbf{1 / f}$ \\
\hline KERTAU48 & Modified Everest & 6377304.063 & 300.8017 \\
\hline KERTAU68 & Modified Everest & 6377304.063 & 300.8017 \\
\hline GENUK & Bessel 1841 & 6377397.155 & 299.1528128 \\
\hline SOUTH ASIA & Modified Fischer 1960 & 6378155 & 298.3 \\
\hline
\end{tabular}




\subsection{Tranformasi dari Datum KERTAU48 ke Datum WGS84}

Informasi tentang transformasi datum dari Datum KERTAU48 ke Datum WGS84 relatif sangat minim. DMA (1991) hanya memberikan tiga parameter transformasi dari datum KERTAU 1948 ke datum WGS84 sebagai berikut:

$$
\begin{aligned}
& \Delta X=-11 \pm 10 \mathrm{~m}, \\
& \Delta Y=+851 \pm 8 \mathrm{~m}, \\
& \Delta \mathrm{Z}=+5 \pm 6 \mathrm{~m} .
\end{aligned}
$$

Berdasarkan parameter tersebut, maka hubungan antara koordinat kartesian $(\mathrm{X}, \mathrm{Y}, \mathrm{Z})$ dalam kedua sistem adalah sebagai berikut :

$$
\left[\begin{array}{c}
X \\
Y \\
Z
\end{array}\right]_{W G S 84}=\left[\begin{array}{c}
X \\
Y \\
Z
\end{array}\right]_{\text {KERTAU 48 }}+\left[\begin{array}{c}
-1 \\
851 \\
5
\end{array}\right] m,
$$

Seandainya kita asumsikan bahwa koordinat titik-titik batas dinyatakan dalam datum KERTAU48, maka koordinat titik-titik batas laut teritorial IndonesiaSingapura dalam sistem WGS84 dapat dihitung. Hasilnya ditunjukkan pada Tabel 7 berikut.

Tabel 7 Koordinat titik-titik batas laut teritorial Indonesia dan Singapura dalam sistem WGS84; dihitung menggunakan model transformasi sederhana dari DMA (1991).

\begin{tabular}{|c|c|c|c|c|}
\hline \multirow{2}{*}{$\begin{array}{c}\text { TITIK } \\
\text { BATAS }\end{array}$} & \multicolumn{2}{|c|}{$\begin{array}{c}\text { PERJANJIAN 1973, } \\
\text { KERTAU48 }\end{array}$} & \multicolumn{2}{c|}{ DATUM WGS84 } \\
\cline { 2 - 5 } & Lintang (U) & Bujur (T) & Lintang (U) & Bujur (T) \\
\hline 1 & $1^{\circ} 10^{\prime} 46^{\prime \prime} .0$ & $103^{\circ} 40^{\prime} 14^{\prime \prime} .6$ & $1^{\circ} 10^{\prime} 45^{\prime \prime} .85$ & $103^{\circ} 40^{\prime} 08^{\prime \prime} .44$ \\
\hline 2 & $1^{\circ} 07^{\prime} 49^{\prime \prime} .3$ & $103^{\circ} 44^{\prime} 26^{\prime \prime} .5$ & $1^{\circ} 07^{\prime} 49^{\prime \prime} .17$ & $103^{\circ} 44^{\prime} 20^{\prime \prime} .31$ \\
\hline 3 & $1^{\circ} 10^{\prime} 17^{\prime \prime} .2$ & $103^{\circ} 48^{\prime} 18^{\prime \prime} .0$ & $1^{\circ} 10^{\prime} 17^{\prime \prime} .05$ & $103^{\circ} 48^{\prime} 11^{\prime \prime} .78$ \\
\hline 4 & $1^{\circ} 11^{\prime} 45^{\prime \prime} .5$ & $103^{\circ} 51^{\prime} 35^{\prime \prime} .4$ & $1^{\circ} 11^{\prime} 45^{\prime \prime} .35$ & $103^{\circ} 51^{\prime} 29^{\prime \prime} .15$ \\
\hline 5 & $1^{\circ} 12^{\prime} 26^{\prime \prime} .1$ & $103^{\circ} 52^{\prime} 50^{\prime \prime} .7$ & $1^{\circ} 12^{\prime} 25^{\prime \prime} .95$ & $103^{\circ} 52^{\prime} 44^{\prime \prime} .44$ \\
\hline 6 & $1^{\circ} 16^{\prime} 10^{\prime \prime} .2$ & $104^{\circ} 02^{\prime} 00^{\prime \prime} .0$ & $1^{\circ} 16^{\prime} 10^{\prime \prime} .03$ & $104^{\circ} 01^{\prime} 53^{\prime \prime} .67$ \\
\hline
\end{tabular}

\subsection{Tranformasi dari Datum KERTAU68 ke Datum WGS84}

Seandainya koordinat titik-titik batas maritim antara Indonesia dan Singapura kita asumsikan mempunyai datum KERTAU68, maka hubungan transformasi yang baru digunakan. JUPEM (2003) dengan menggunakan model transformasi 
Bursa-Wolf telah menentukan tiga set parameter transformasi dari datum WGS84 ke datum KERTAU68 tergantung wilayah cakupan. Untuk lokasi titiktitik batas Indonesia - Singapura yang berada pada wilayah Block 1, maka parameter transformasinya adalah:

$$
\begin{aligned}
& \operatorname{Dx}(\mathrm{m})=+379.947, \\
& \operatorname{Dy}(\mathrm{m})=-770.555, \\
& \operatorname{Dz}(\mathrm{m})=+88.069, \\
& \mathrm{Rx}=+2.698 \% / \rho, \\
& \mathrm{Ry}=+1.522 \% / \rho, \\
& \mathrm{Rz}=-12.113 \% / \rho, \\
& \text { Scal }=-0.791 \times 10^{-6},
\end{aligned}
$$

dimana $\rho=206264.8 "$. Dalam hal ini formulasi hubungan antar dua sistem koordinat adalah sebagai berikut:

$\left[\begin{array}{c}X \\ Y \\ Z\end{array}\right]_{\text {KERTAU 68 }}=\left[\begin{array}{c}D x \\ D y \\ D z\end{array}\right]_{W G S 84}+(1+S c a l) \cdot\left[\begin{array}{ccc}1 & R_{z} & -R_{y} \\ -R_{z} & 1 & R_{x} \\ R_{y} & -R_{x} & 1\end{array}\right] \cdot\left[\begin{array}{c}X \\ Y \\ Z\end{array}\right]_{W G S 84}$

Seandainya kita asumsikan bahwa koordinat titik-titik batas mempunyai datum KERTAU68 dan model transformasi Bursa-Wolf seperti yang diberikan rumus (2) digunakan, maka koordinat titik-titik batas laut teritorial IndonesiaSingapura dalam sistem WGS84 dapat dihitung. Hasilnya ditunjukkan pada Tabel 8 berikut.

Tabel 8 Koordinat titik-titik batas laut teritorial Indonesia dan Singapura dalam sistem WGS84; dihitung menggunakan model transformasi Bursa-Wolf dari JUPEM (2003).

\begin{tabular}{|c|c|c|c|c|}
\hline \multirow{2}{*}{$\begin{array}{c}\text { TITIK } \\
\text { BATAS }\end{array}$} & \multicolumn{2}{|c|}{$\begin{array}{c}\text { PERJANJIAN 1973, } \\
\text { KERTAU68 }\end{array}$} & \multicolumn{2}{c|}{ DATUM WGS84 } \\
\cline { 2 - 5 } & Lintang (U) & Bujur (T) & Lintang (U) & Bujur (T) \\
\hline 1 & $1^{\circ} 10^{\prime} 46^{\prime \prime} .0$ & $103^{\circ} 40^{\prime} 14^{\prime \prime} .6$ & $1^{\circ} 10^{\prime} 45^{\prime \prime} .82$ & $103^{\circ} 40^{\prime} 08^{\prime \prime} .52$ \\
\hline 2 & $1^{\circ} 07^{\prime} 49^{\prime \prime} .3$ & $103^{\circ} 44^{\prime} 26^{\prime \prime} .5$ & $1^{\circ} 07^{\prime} 49^{\prime \prime} .13$ & $103^{\circ} 44^{\prime} 20^{\prime \prime} .39$ \\
\hline 3 & $1^{\circ} 10^{\prime} 17^{\prime \prime} .2$ & $103^{\circ} 48^{\prime} 18^{\prime \prime} .0$ & $1^{\circ} 10^{\prime} 17^{\prime \prime} .02$ & $103^{\circ} 48^{\prime} 11^{\prime \prime} .86$ \\
\hline 4 & $1^{\circ} 11^{\prime} 45^{\prime \prime} .5$ & $103^{\circ} 51^{\prime} 35^{\prime \prime} .4$ & $1^{\circ} 11^{\prime} 45^{\prime \prime} .32$ & $103^{\circ} 51^{\prime} 29^{\prime \prime} .23$ \\
\hline 5 & $1^{\circ} 12^{\prime} 26^{\prime \prime} .1$ & $103^{\circ} 52^{\prime} 50^{\prime \prime} .7$ & $1^{\circ} 12^{\prime} 25^{\prime \prime} .91$ & $103^{\circ} 52^{\prime} 44^{\prime \prime} .52$ \\
\hline 6 & $1^{\circ} 16^{\prime} 10^{\prime \prime} .2$ & $104^{\circ} 02^{\prime} 00^{\prime \prime} .0$ & $1^{\circ} 16^{\prime} 10^{\prime \prime} .00$ & $104^{\circ} 01^{\prime} 53^{\prime \prime} .75$ \\
\hline
\end{tabular}




\subsection{Tranformasi dari Datum GENUK ke Datum WGS84}

Informasi tentang transformasi datum dari Datum GENUK (BATAVIA) ke Datum WGS84 relatif sangat minim. DMA (1991) hanya memberikan tiga parameter transformasi dari datum GENUK ke datum WGS84 sebagai berikut :

$$
\begin{aligned}
& \Delta X=-377 \pm 3 \mathrm{~m} \\
& \Delta \mathrm{Y}=+681 \pm 3 \mathrm{~m}, \\
& \Delta \mathrm{Z}=-50 \pm 3 \mathrm{~m} .
\end{aligned}
$$

Berdasarkan parameter tersebut, maka hubungan antara koordinat kartesian $(\mathrm{X}, \mathrm{Y}, \mathrm{Z})$ dalam kedua sistem adalah sebagai berikut :

$$
\left[\begin{array}{c}
X \\
Y \\
Z
\end{array}\right]_{W G S 84}=\left[\begin{array}{c}
X \\
Y \\
Z
\end{array}\right]_{\text {GENUK }}+\left[\begin{array}{c}
-377 \\
681 \\
-50
\end{array}\right] \mathrm{m},
$$

Seandainya kita asumsikan bahwa koordinat titik-titik batas dinyatakan dalam datum GENUK, maka koordinat titik-titik batas laut teritorial IndonesiaSingapura dalam sistem WGS84 dapat dihitung. Hasilnya ditunjukkan pada Tabel 9 berikut.

Tabel 9 Koordinat titik-titik batas laut teritorial Indonesia dan Singapura dalam sistem WGS84; dihitung menggunakan model transformasi sederhana dari $D M A$ (1991).

\begin{tabular}{|c|c|c|c|c|}
\hline \multirow{2}{*}{$\begin{array}{c}\text { TITIK } \\
\text { BATAS }\end{array}$} & \multicolumn{2}{|c|}{ PERJANJIAN 1973, GENUK } & \multicolumn{2}{c|}{ DATUM WGS84 } \\
\cline { 2 - 5 } & Lintang (U) & Bujur (T) & Lintang (U) & Bujur (T) \\
\hline 1 & $01^{\circ} 10^{\prime} 46^{\prime \prime} .0$ & $103^{\circ} 40^{\prime} 14^{\prime \prime} .6$ & $01^{\circ} 10^{\prime} 43^{\prime \prime} .96$ & $103^{\circ} 40^{\prime} 21^{\prime \prime} .24$ \\
\hline 2 & $01^{\circ} 07^{\prime} 49^{\prime \prime} .3$ & $103^{\circ} 44^{\prime} 26^{\prime \prime} .5$ & $01^{\circ} 07^{\prime} 47^{\prime \prime} .28$ & $103^{\circ} 44^{\prime} 33^{\prime \prime} .11$ \\
\hline 3 & $01^{\circ} 10^{\prime} 17^{\prime \prime} .2$ & $103^{\circ} 48^{\prime} 18^{\prime \prime} .0$ & $01^{\circ} 10^{\prime} 15^{\prime \prime} .16$ & $103^{\circ} 48^{\prime} 24^{\prime \prime} .59$ \\
\hline 4 & $01^{\circ} 11^{\prime} 45^{\prime \prime} .5$ & $103^{\circ} 51^{\prime} 35^{\prime \prime} .4$ & $01^{\circ} 11^{\prime} 43^{\prime \prime} .45$ & $103^{\circ} 51^{\prime} 41^{\prime \prime} .96$ \\
\hline 5 & $01^{\circ} 12^{\prime} 26^{\prime \prime} .1$ & $103^{\circ} 52^{\prime} 50^{\prime \prime} .7$ & $01^{\circ} 12^{\prime} 24^{\prime \prime} .05$ & $103^{\circ} 52^{\prime} 57^{\prime \prime} .25$ \\
\hline 6 & $01^{\circ} 16^{\prime} 10^{\prime \prime} .2$ & $104^{\circ} 02^{\prime} 00^{\prime \prime} .0$ & $01^{\circ} 16^{\prime} 08^{\prime \prime} .13$ & $104^{\circ} 02^{\prime} 06^{\prime \prime} .49$ \\
\hline
\end{tabular}

\subsection{Tranformasi dari Datum SOUTH ASIA ke Datum WGS84}

Informasi tentang transformasi datum dari Datum SOUTH ASIA ke Datum WGS84 relatif sangat minim. DMA (1991) hanya memberikan tiga parameter transformasi dari datum SOUTH ASIA ke datum WGS84 sebagai berikut: 


$$
\begin{aligned}
& \Delta X=+7 \pm 10 \mathrm{~m} \\
& \Delta \mathrm{Y}=-10 \pm 8 \mathrm{~m} \\
& \Delta \mathrm{Z}=-26 \pm 6 \mathrm{~m} .
\end{aligned}
$$

Berdasarkan parameter tersebut, maka hubungan antara koordinat kartesian $(\mathrm{X}, \mathrm{Y}, \mathrm{Z})$ dalam kedua sistem adalah sebagai berikut :

$$
\left[\begin{array}{c}
X \\
Y \\
Z
\end{array}\right]_{W G S 84}=\left[\begin{array}{l}
X \\
Y \\
Z
\end{array}\right]_{\text {SOUTHASIA }}+\left[\begin{array}{c}
+7 \\
-10 \\
-26
\end{array}\right] m,
$$

Seandainya kita asumsikan bahwa koordinat titik-titik batas dinyatakan dalam datum SOUTH ASIA, maka koordinat titik-titik batas laut teritorial IndonesiaSingapura dalam sistem WGS84 dapat dihitung. Hasilnya ditunjukkan pada Tabel 10 berikut.

Tabel 10 Koordinat titik-titik batas laut teritorial Indonesia dan Singapura dalam sistem WGS84; dihitung menggunakan model transformasi sederhana dari DMA (1991).

\begin{tabular}{|c|c|c|c|c|}
\hline \multirow{2}{*}{$\begin{array}{c}\text { TITIK } \\
\text { BATAS }\end{array}$} & \multicolumn{2}{|c|}{$\begin{array}{c}\text { PERJANJIAN 1973, SOUTH } \\
\text { ASIA }\end{array}$} & \multicolumn{2}{c|}{ DATUM WGS84 } \\
\cline { 2 - 5 } & Lintang (U) & Bujur (T) & Lintang (U) & Bujur (T) \\
\hline 1 & $1^{\circ} 10^{\prime} 46^{\prime \prime} .0$ & $103^{\circ} 40^{\prime} 14^{\prime \prime} .6$ & $01^{\circ} 10^{\prime} 45^{\prime \prime} .16$ & $\begin{array}{c}103^{\circ} 40^{\prime} \\
14^{\prime \prime} .46\end{array}$ \\
\hline 2 & $1^{\circ} 07^{\prime} 49^{\prime \prime} .3$ & $103^{\circ} 44^{\prime} 26^{\prime \prime} .5$ & $01^{\circ} 07^{\prime} 48^{\prime \prime} .46$ & $\begin{array}{c}103^{\circ} 44^{\prime} \\
26^{\prime \prime} .36\end{array}$ \\
\hline 3 & $1^{\circ} 10^{\prime} 17^{\prime \prime} .2$ & $103^{\circ} 48^{\prime} 18^{\prime \prime} .0$ & $01^{\circ} 10^{\prime} 16^{\prime \prime} .36$ & $\begin{array}{c}103^{\circ} 48^{\prime} \\
17^{\prime \prime} .86\end{array}$ \\
\hline 4 & $1^{\circ} 11^{\prime} 45^{\prime \prime} .5$ & $103^{\circ} 51^{\prime} 35^{\prime \prime} .4$ & $01^{\circ} 11^{\prime} 44^{\prime \prime} .67$ & $\begin{array}{c}103^{\circ} 51^{\prime} \\
35^{\prime \prime} .26\end{array}$ \\
\hline 5 & $1^{\circ} 12^{\prime} 26^{\prime \prime} .1$ & $103^{\circ} 52^{\prime} 50^{\prime \prime} .7$ & $01^{\circ} 12^{\prime} 25^{\prime \prime} .27$ & $\begin{array}{c}103^{\circ} 52^{\prime} \\
50^{\prime \prime} .56\end{array}$ \\
\hline 6 & $1^{\circ} 16^{\prime} 10^{\prime \prime} .2$ & $104^{\circ} 02^{\prime} 00^{\prime \prime} .0$ & $01^{\circ} 16^{\prime} 09^{\prime \prime} .37$ & $\begin{array}{c}104^{\circ} 01^{\prime} \\
59^{\prime \prime} .86\end{array}$ \\
\hline
\end{tabular}

\section{$4 \quad$ Analisis dan Permasalahan yang Terkait}

Ketidak jelasan tentang datum geodetik dari koordinat titik-titik batas akan menimbulkan beberapa permasalahan operasional di lapangan dan disamping 
itu juga akan berpengaruh terhadap beberapa aspek spasial lainnya. Berikut ini beberapa permasalahan tersebut akan didiskusikan dan dianalisa.

\subsection{Perubahan Nilai Koordinat Titik Batas}

Setiap titik akan punya koordinat yang berbeda pada datum geodetik yang berbeda. Penggunaan datum geodetik yang salah akan mengakibatkan terjadinya perubahan nilai koordinat titik dari posisinya yang sebenarnya. Dalam kasus titik-titik batas laut teritorial antara Indonesia dan Singapura, Tabel 11 menunjukkan besarnya perubahan posisi geografis titik batas dari datum geodetik alternatif terhadap posisinya dalam datum WGS84 hasil transformasi.

Tabel 11 Selisih koordinat geodetik $(\mathrm{d} \varphi, \mathrm{d} \lambda)$ dari titik-titik batas laut territorial Indonesia dan Singapura dalam sistem WGS84, dan pergeseran posisi geografisnya (d) dalam WGS84.

\begin{tabular}{|c|c|c|c|c|c|c|}
\hline \multirow{2}{*}{$\begin{array}{c}\text { TITIK } \\
\text { BATAS }\end{array}$} & \multicolumn{3}{|c|}{$\begin{array}{c}\text { Koordinat KERTAU48 } \\
\text { dikurangi Koordinat WGS84 nya }\end{array}$} & \multicolumn{3}{|c|}{$\begin{array}{c}\text { Koordinat KERTAU68 } \\
\text { dikurangi Koordinat WGS84 nya }\end{array}$} \\
\hline & $\mathrm{d} \varphi$ & $\mathrm{d} \lambda$ & d (m) & $\mathrm{d} \varphi$ & $\mathrm{d} \lambda$ & d (m) \\
\hline 1 & $0 " .15$ & 6".16 & 190.5 & $0 " .18$ & $6 " .08$ & 188.0 \\
\hline 2 & $0 " .13$ & 6".19 & 191.4 & $0 " .17$ & 6".11 & 189.0 \\
\hline 3 & $0 " .15$ & $6 " .22$ & 192.4 & $0 " .18$ & 6".14 & 189.9 \\
\hline 4 & $0 " .15$ & $6 " .25$ & 193.3 & $0 " .18$ & $6 " .17$ & 190.8 \\
\hline 5 & $0 " .15$ & $6 " .26$ & 193.6 & 0".19 & $6 " .18$ & 191.1 \\
\hline 6 & $0 " .17$ & $6 " .33$ & 195.8 & $0 " .20$ & $6 " .25$ & 193.3 \\
\hline \multirow{2}{*}{$\begin{array}{c}\text { TITIK } \\
\text { BATAS }\end{array}$} & \multicolumn{3}{|c|}{$\begin{array}{c}\text { Koordinat GENUK } \\
\text { dikurangi Koordinat WGS84 nya }\end{array}$} & \multicolumn{3}{|c|}{$\begin{array}{c}\text { Koordinat SOUTH ASIA } \\
\text { dikurangi Koordinat WGS84 nya }\end{array}$} \\
\hline & $\mathrm{d} \varphi$ & $\mathrm{d} \lambda$ & d (m) & $\mathrm{d} \varphi$ & $\mathbf{d} \lambda$ & d (m) \\
\hline 1 & $2 " .04$ & $-6 " .64$ & 214.7 & $0 " .84$ & $0 " .14$ & 26.02 \\
\hline 2 & $2 " .02$ & $-6 " .61$ & 213.7 & $0 " .84$ & $0 " .14$ & 26.03 \\
\hline 3 & $2 " .04$ & $-6 " .59$ & 213.0 & 0".84 & 0".14 & 26.02 \\
\hline 4 & $2 " .05$ & $-6 " .56$ & 212.4 & $0 " .83$ & $0 " .14$ & 26.01 \\
\hline 5 & $2 " .05$ & $-6 " .55$ & 212.2 & $0 " .83$ & $0 " .14$ & 26.00 \\
\hline 6 & $2 " .07$ & $-6 " .49$ & 210.5 & $0 " .83$ & $0 " .14$ & 25.98 \\
\hline
\end{tabular}

Dari Tabel 11 terlihat, bahwa selisih nilai koordinat tergantung pada datum geodetik asal dari koordinat dalam perjanjian batas (yang tidak diketahui secara jelas), sehingga perubahan posisinya terhadap koordinatnya dalam datum geodetik WGS84 bervariasi untuk empat datum alternatif yang dikaji. Nilai d pada Tabel 11 ditentukan dengan metode Vincenty [Vincenty, (1975).

Pergeseran nilai paling besar terjadi seandainya datum asal titik batas adalah datum GENUK, yaitu sekitar 210 sampai $215 \mathrm{~m}$. Sedangkan pergeseran nilai paling kecil terjadi seandainya datum geodetik asal adalah datum SOUTH ASIA, dimana pergeseran posisi berkisar sekitar $26 \mathrm{~m}$. Seandainya datum 
asalnya adalah KERTAU48, maka pergeseran posisi adalah sekitar 190 - 196 m; dan kalau datum asalnya adalah KERTAU68 maka pergeseran posisinya adalah sekitar $188-193 \mathrm{~m}$.

Perubahan nilai koordinat titik batas dalam dua-dimensi akibat adanya perbedaan datum geodetik juga dapat diilustrasikan seperti yang ditunjukkan pada Gambar 3 berikut. Dari Gambar ini dapat disadari bahwa perbedaan datum dapat mempengaruhi prinsip geometrik yang digunakan dalam penetapan lokasi titik batas sebelumnya, seperti prinsip sama-jarak (equidistance); terutama untuk kasus-kasus dimana datum asalnya adalah KERTAU48, KERTAU68 atau GENUK.

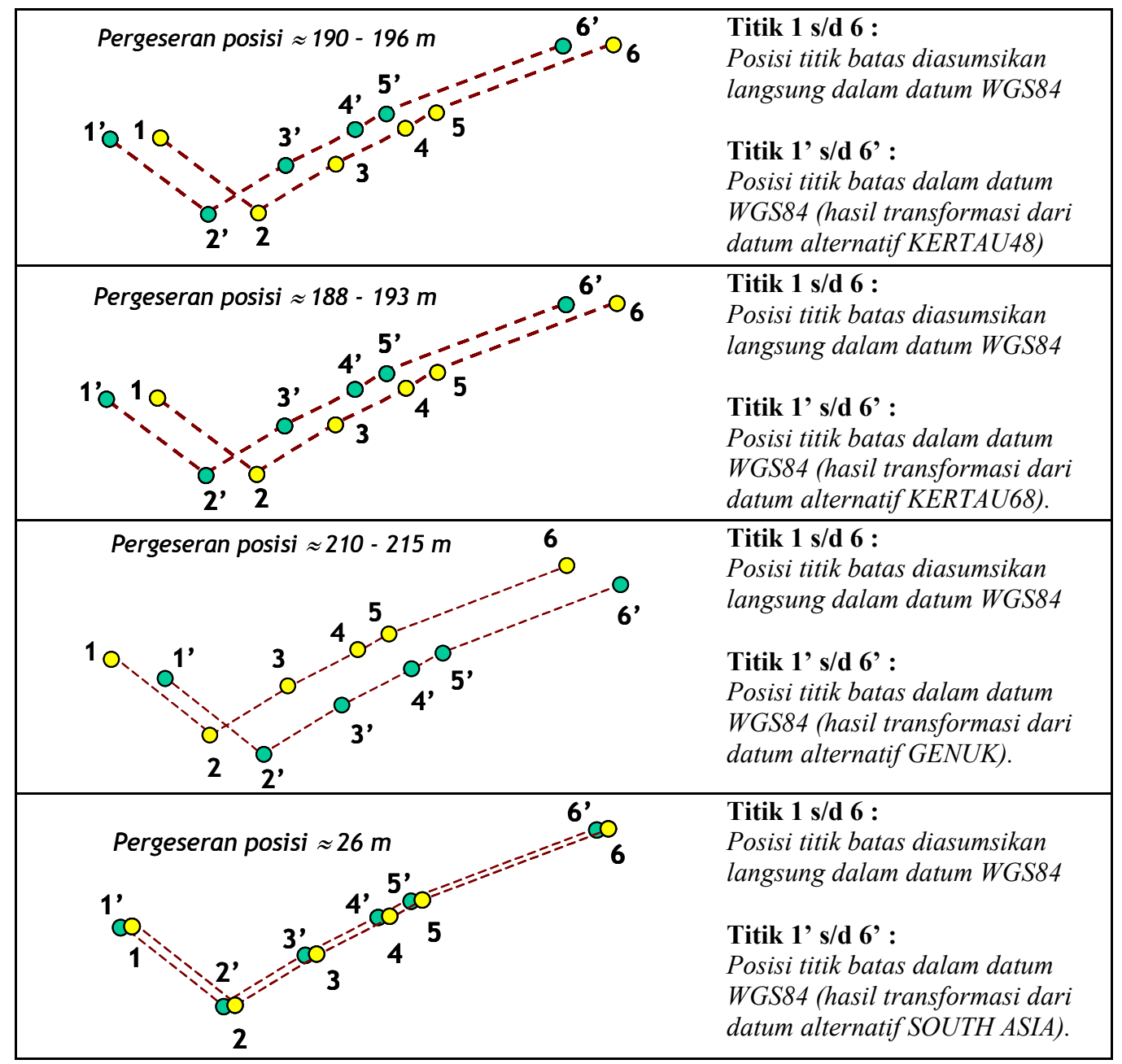

Gambar 3 Pergeseran posisi titik batas karena kesalahan datum geodetik. 


\subsection{Jarak Antar Titik Batas}

Dalam Perjanjian Batas Laut 1973 antara Indonesia dan Singapura dinyatakan bahwa garis batas menghubungkan titik-titik berkoordinat geografis; sehingga jarak antara titik batas pada dasarnya adalah adalah jarak antar titik batas di permukaan ellipsoid referensi dari datum geodetik yang digunakan. Oleh sebab itu jarak antar titik batas juga akan tergantung pada datum geodetik dari koordinat titik-titik batas yang bersangkutan. Hal ini diilustrasikan oleh hasil yang diberikan pada Tabel 12 dan 13. Dari kedua Tabel ini terlihat bahwa efek perbedaan datum geodetik pada koordinat titik-titik batas laut teritorial Indonesia dengan Singapura terhadap jarak antar titik batas bervariasi antara sekitar 0.0 sampai $2.2 \mathrm{~m}$ tergantung jarak antar titik batas dan datum geodetiknya. Untuk semua datum geodetik, variasi terbesar terjadi pada jarak antar titik-titik batas 5 dan 6 yang memang paling panjang. Perubahan jarak paling kecil terjadi untuk datum SOUTH ASIA. Sedangkan untuk ketiga datum lainnya, perubahan jarak relatif hampir sama yaitu dalam orde sekitar 1-2 meter.

Tabel 12 Jarak antar titik batas pada ellipsoid WGS84.

\begin{tabular}{|c|c|c|c|c|c|c|}
\hline Titik Batas & 1 & 2 & 3 & 4 & 5 & 6 \\
\hline $\begin{array}{l}\text { Jarak geografis } \\
\text { (Koordinat } \\
\text { Perjanjian 1973, } \\
\text { Datum WGS84) }\end{array}$ & & 9492.35 & 8477.02 & 6678.25 & 2640.90 & 18323.56 \\
\hline $\begin{array}{l}\text { Jarak geografis } \\
\text { (WGS84 dari } \\
\text { KERTAU48) }\end{array}$ & & 9491.24 & 8475.91 & 6677.40 & 2640.62 & 18321.32 \\
\hline $\begin{array}{l}\text { Jarak geografis } \\
\text { (WGS84 dari } \\
\text { KERTAU68) } \\
\end{array}$ & & 9491.41 & 8476.07 & 6677.40 & 2640.48 & 18321.44 \\
\hline $\begin{array}{l}\text { Jarak geografis } \\
\text { (WGS84 dari } \\
\text { GENUK) }\end{array}$ & & 9491.29 & 8476.09 & 6677.49 & 2640.59 & 18321.45 \\
\hline $\begin{array}{l}\text { Jarak geografis } \\
\text { (WGS84 dari } \\
\text { SOUTH ASIA) }\end{array}$ & & 9492.38 & 8477.02 & 6678.29 & 2640.90 & 18323.59 \\
\hline
\end{tabular}

Tabel 13 Variasi jarak (dalam m) antar titik batas pada ellipsoid WGS84.

\begin{tabular}{|l|c|c|c|c|c|c|}
\hline Titik Batas & $\mathbf{1}$ & $\mathbf{2}$ & $\mathbf{3}$ & $\mathbf{4}$ & $\mathbf{5}$ & $\mathbf{6}$ \\
\hline $\begin{array}{l}\text { Jarak geografis } \\
\text { (Koordinat Perjanjian 1973, } \\
\text { Datum WGS84) }\end{array}$ & 0 & 0 & 0 & 0 & 0 \\
\hline $\begin{array}{l}\text { Jarak geografis } \\
\text { (WGS84 dari KERTAU48) }\end{array}$ & -1.11 & -1.11 & -0.85 & -0.28 & -2.24 \\
\hline $\begin{array}{l}\text { Jarak geografis } \\
\text { (WGS84 dari KERTAU68) }\end{array}$ & -0.94 & -0.95 & -0.85 & -0.42 & -2.12 \\
\hline
\end{tabular}




\begin{tabular}{|l|ccccc|}
\hline $\begin{array}{l}\text { Jarak geografis } \\
\text { (WGS84 dari GENUK) }\end{array}$ & -1.06 & -0.93 & -0.76 & -0.31 & -2.11 \\
\hline $\begin{array}{l}\text { Jarak geografis } \\
\text { (WGS84 dari SOUTH }\end{array}$ & 0.03 & 0.00 & 0.04 & 0.00 & 0.03 \\
\begin{tabular}{l} 
ASIA) \\
\hline
\end{tabular}
\end{tabular}

\subsection{Jarak Terhadap Titik Dasar}

Keenam titik batas laut teritorial antara Indonesia dan Singapura ditentukan berdasarkan prinsip sama-jarak (equidistan principle) dan negosiasi. Prinsip sama jarak digunakan untuk penentuan posisi titik-titik batas 4, 5 dan 6; dan prinsip negosiasi digunakan untuk titik-titik batas 1, 2 dan 3. Jarak antara titiktitik batas tersebut terhadap titik-titik dasar (basepoints) di wilayah Indonesia dan Singapura ditunjukkan pada Tabel 14. Secara umum dari Tabel 14 terlihat bahwa titik-titik batas 1, 2 dan 3 terletak lebih jauh dari wilayah Singapura dibandingkan dari wilayah Indonesia, yaitu masing-masing lebih jauh $2037.2 \mathrm{~m}$, $740.8 \mathrm{~m}$ dan $1296.4 \mathrm{~m}$. Bahkan menurut The Geographer (1974), semua titik batas kecuali titik 5 terletak di sebelah Selatan garis median antara Indonesia dan Singapura, yaitu garis yang direkonstruksi menggunakan sistem garis pangkal lurus Indonesia dan sistem low-tide elevation nya Singapura. Bahkan titik 2 berada dalam perairan internal dari wilayah Indonesia (yaitu di sebelah Selatan sistem garis pangkal Kepulauan).

Perubahan datum geodetik juga akan mempengaruhi jarak antara titik-titik dasar dengan titik-titik batas. Pada Tabel 14 diberikan nama dari dari lima titik dasar yang digunakan oleh pihak Indonesia dalam penentuan posisi titik-titik batas di Selat Singapura. Kalau kita mengacu pada Peraturan Pemerintah (PP) No. 4 Prp Tahun 1960 dan PP No. 38 tahun 2002 maka nomor dan koordinat dari titiktitik dasar yang berada di sekitar kawasan batas laut Indonesia-Singapura adalah seperti yang diberikan pada Tabel 15 dan Gambar 4.

Tabel 14 Jarak titik-titik batas terhadap titik-titik dasar di wilayah Indonesia dan wilayah Singapura dalam Datum Bukit Asa [The Geographer, 1974].

\begin{tabular}{|c|l|c|l|c|}
\hline $\begin{array}{c}\text { Titik } \\
\text { Batas }\end{array}$ & \multicolumn{2}{|c|}{$\begin{array}{c}\text { Jarak Titik Batas dari } \\
\text { Wilayah Indonesia (dalam m) }\end{array}$} & \multicolumn{2}{c|}{$\begin{array}{c}\text { Jarak Titik Batas dari Wilayah } \\
\text { Singapura (dalam m) }\end{array}$} \\
\hline 1 & P. Nipah & 3148.4 & P. Sudong & 5185.6 \\
\hline 2 & P. Takong Besar & 2500.2 & P. Satumu & 3241.0 \\
\hline 3 & Buffalo Rock & 2037.2 & P. Sebarok & 3333.6 \\
\hline 4 & Bt. Berhanti & 2407.6 & P. Sakijang Bendera & 2407.6 \\
\hline 5 & Bt. Berhanti & 2407.6 & $\begin{array}{l}\text { Pulau kecil tak bernama di } \\
\text { sebelah Timur P. Sakijang } \\
\text { Petepah }\end{array}$ & 2407.6 \\
\hline 6 & Tg. Sengkuang & 8611.8 & Tg. Bedok & 8611.8 \\
\hline
\end{tabular}


Tabel 15 Titik-titik Dasar Indonesia di Sekitar Kawasan Batas Laut IndonesiaSingapura.

\begin{tabular}{|l|c|c|c|c|l|}
\hline \multirow{2}{*}{$\begin{array}{c}\text { Titik } \\
\text { Dasar }\end{array}$} & \multicolumn{2}{|c|}{$\begin{array}{c}\text { PP 4 Prp 1960 } \\
\text { (Datum Tidak Disebut) }\end{array}$} & \multicolumn{2}{|c|}{$\begin{array}{c}\text { PP 38/2002 } \\
\text { (Datum WGS84) }\end{array}$} & \multirow{2}{*}{ Lokasi } \\
\cline { 2 - 5 } & Lintang & Bujur & Lintang & Bujur & \\
\hline TD.190 & $01^{\circ} 09.2^{\prime}$ & $103^{\circ} 39.3^{\prime}$ & $01^{\circ} 09^{\prime} 13^{\prime \prime}$ & $103^{\circ} 39^{\prime} 11^{\prime \prime}$ & P. Nipa \\
\hline TD.190A & - & - & $01^{\circ} 09^{\prime} 12^{\prime \prime}$ & $103^{\circ} 39^{\prime} 21^{\prime \prime}$ & P. Nipa \\
\hline TD.191 & $01^{\circ} 07.9^{\prime}$ & $103^{\circ} 42.0^{\prime}$ & $01^{\circ} 07^{\prime} 44^{\prime \prime}$ & $103^{\circ} 41^{\prime} 58^{\prime \prime}$ & P. Pelampong \\
\hline TD.191A & - & - & $01^{\circ} 07^{\prime} 27^{\prime \prime}$ & $103^{\circ} 46^{\prime} 30^{\prime \prime}$ & Kr. Helen Mars \\
\hline TD.191B & - & - & $01^{\circ} 09^{\prime} 26^{\prime \prime}$ & $103^{\circ} 48^{\prime} 50^{\prime \prime}$ & Kr. Benteng \\
\hline TD.192 & $01^{\circ} 10.9^{\prime}$ & $103^{\circ} 52.9^{\prime}$ & $01^{\circ} 11^{\prime} 06^{\prime \prime}$ & $103^{\circ} 52^{\prime} 57^{\prime \prime}$ & Batu Berhanti \\
\hline TD.193 & $01^{\circ} 12.5^{\prime}$ & $104^{\circ} 04.3^{\prime}$ & $01^{\circ} 12^{\prime} 29^{\prime \prime}$ & $104^{\circ} 04^{\prime} 47^{\prime \prime}$ & P. Nongsa \\
\hline
\end{tabular}

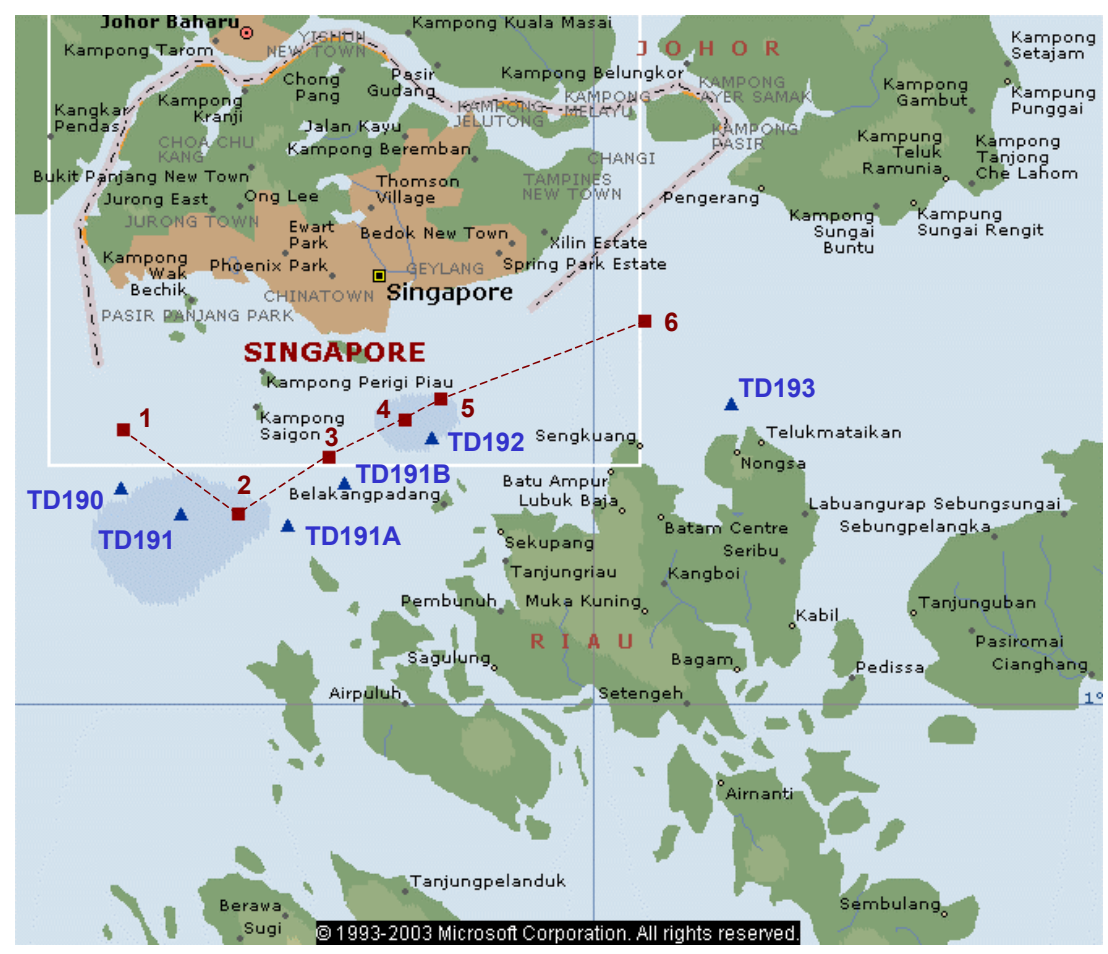

Gambar 4 Titik-titik Dasar Indonesia di Sekitar Kawasan Batas Laut Indonesia-Singapura.

Dari Gambar 4 terlihat bahwa rekonstruksi ke enam titik batas laut teritorial antara Indonesia dan Malaysia, seandainya diperlukan, akan dapat dilaksanakan dari enam titik dasar Indonesia (e.g. TD190 s/d TD193) yang berada di sekitar kawasan tersebut yang koordinatnya telah diketahui dalam datum geodetik 
WGS84. Jarak dari titik-titik dasar tersebut ke enam titik batas dapat dilihat pada contoh matriks jarak pada Tabel 16, dimana datum geodetik titik asal diasumsikan KERTAU48 dan KERTAU68.

Tabel 16 Tabel 16. Matriks Jarak Geodetik antara Titik Dasar dan Titik Batas Laut Teritorial Antara Indonesia dan Singapura pada Ellipsoid WGS84.

Koordinat titik batas adalah koordinat WGS84 yang ditransformasikan dari datum KERTAU48 (K48) atau KERTAU68 (K68).

\begin{tabular}{|c|c|c|c|c|c|c|c|}
\hline \multirow{2}{*}{$\begin{array}{c}\text { Titik Batas } \\
\text { \& Datum }\end{array}$} & \multicolumn{7}{|c|}{ Titik-Titik Dasar } \\
\cline { 2 - 8 } 1 & K48 & 3359.6 & 6532.3 & - & - & - & TD0 \\
\hline & K68 & 3360.1 & 6530.2 & - & - & - & - \\
\hline $\mathbf{2}$ & K48 & - & 4402.5 & 4066.9 & - & - & - \\
\hline & K68 & - & 4405.0 & 4064.3 & - & - & - \\
\hline $\mathbf{3}$ & K48 & - & - & 6097.7 & 1963.4 & - & - \\
\hline & K68 & - & - & 6098.2 & 1961.2 & - & - \\
\hline $\mathbf{4}$ & K48 & - & - & - & 6521.4 & 2972.7 & - \\
\hline & K68 & - & - & - & 6522.6 & 2970.1 & - \\
\hline $\mathbf{5}$ & K48 & - & - & - & - & 2486.2 & 22338.3 \\
\hline & K68 & - & - & - & - & 2484.6 & 22335.9 \\
\hline $\mathbf{6}$ & K48 & - & - & - & - & 19038.7 & 8648.9 \\
\hline & K68 & - & - & - & - & 19040.3 & 8646.7 \\
\hline
\end{tabular}

Tabel 16 hanya memberikan jarak dengan asumsi titik batas mempunyai datum KERTAU48 atau KERTAU68. Untuk datum GENUK dan SOUTH ASIA, dengan mengacu besarnya variasi jarak pada Tabel 11 sebelumnya, maka variasi jarak pada datum GENUK dan SOUTH ASIA seperti yang ditunjukkan Tabel 16 pada dasarnya akan relatif sama, yaitu pada level sekitar 1-2 meter.

\subsection{Efek Terhadap Segmen Garis Batas Lainnya}

Karena koordinat geografis suatu titik tergantung pada datum geodetiknya, maka segmen-segmen garis batas yang berhubungan juga akan dipengaruhi oleh datum geodetik yang digunakan.

Secara teoritis segmen-segmen garis batas yang berhubungan sebaiknya mempunyai datum geodetik yang sama untuk menjaga kontinuitas dan konsistensi segmen-segmen garis batas tersebut seandainya dihubungkan. Perbedaan datum geodetik dari segmen-segmen garis batas yang berhubungan juga akan mengakibatkan perbedaan koordinat pada titik batas bersama (junction point) dari segmen-segmen garis batas tersebut. Dan ini tentunya akan menimbulkan permasalahan lainnya yang terkait. 
Dalam konteks batas laut teritorial antara Indonesia dan Malaysia, penetapan datum geodetik yang akan digunakan perlu mempertimbangkan datum geodetik dari segmen batas laut teritorial dan landas kontinen antara Indonesia dan Malaysia di Selat Malaka dan juga datum geodetik dari segmen batas landas kontinen antara Indonesia dan Malaysia di Laut Cina Selatan bagian Barat.

Seperti yang diilustrasikan pada Gambar 5 ada dua segmen batas laut yang perlu disepakati oleh Indonesia, Singapura dan Malaysia. Seandainya dilaksanakan pembicaraan tiga negara dalam hal ini, maka masalah datum geodetik yang digunakan juga perlu dibicarakan secara serius, karena hal ini tidak hanya mempengaruhi segmen batas laut teritorial Indonesia-Singapura, tapi juga segmen batas laut teritorial dan landas kontinen antara Indonesia dan Malaysia. Sebaiknya untuk semua segmen batas yang saling berhubungan nantinya, koordinat titik-titik batasnya dinyatakan dalam datum geodetik yang sama serta mudah untuk direkonstruksikan seandainya diperlukan.

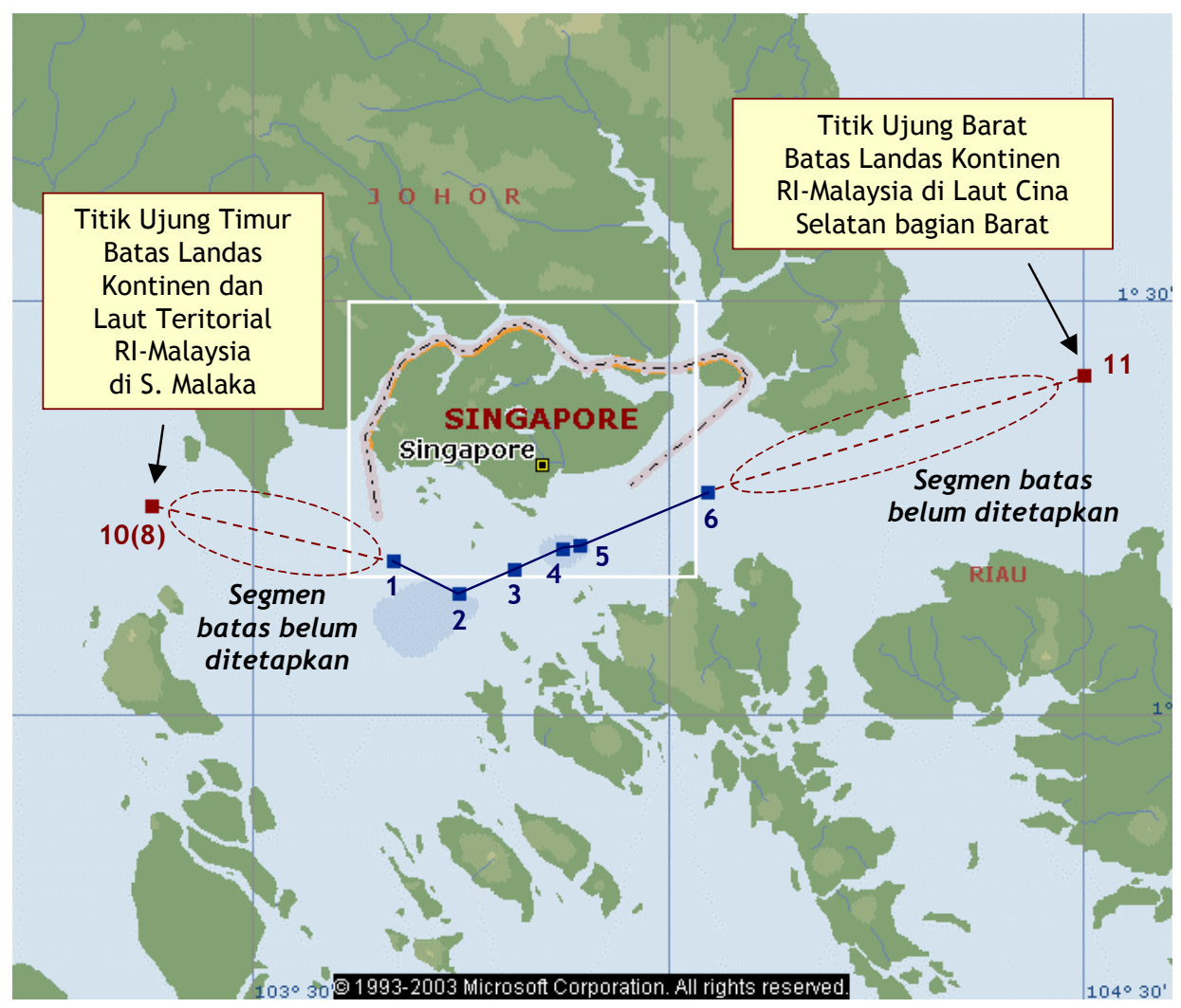

Gambar 5 Konfigurasi Batas Laut Indonesia, Singapura dan Malaysia yang belum terselesaikan di kawasan Selat Singapura dan Selat Malaka. 


\subsection{Pengaruh dari Proses Penambangan Pasir dan Reklamasi Pantai}

Dalam konteks batas laut teritorial antara Indonesia dan Singapura, proses penambangan pasir di kawasan Kepulauan Riau serta reklamasi pantai Singapura adalah dua hal yang banyak didiskusikan karena secara langsung punya potensi untuk mengubah lokasi titik dasar maupun obyek referensi yang digunakan dalam penetapan titik-titik batas laut antara Indonesia dan Singapura.

Sebagai contoh adalah kasus pulau Nipa yang merupakan salah satu titik dasar dalam penentuan batas negara, yaitu TD190 dan TD190A. Dalam setahun terakhir, seiring maraknya aksi penambangan dan ekspor pasir laut di kawasan Kepulauan Riau, pulau tersebut nyaris tenggelam. Menurut Kompas (2003a), ketika puncak pasang, tinggi daratan di pulau itu tinggal 0.5 meter dari permukaan laut atau sekitar 90 persen sudah tenggelam. Apabila pulau itu tenggelam, otomatis TD190 dan TD190A akan hilang dan akibatnya akan menimbulkan komplikasi dalam rekonstruksi batas laut antara Indonesia dan Singapura maupun dan Indonesia dan Malaysia.

Disamping itu reklamasi besar-besaran yang dilaksanakan oleh pemerintah Singapura juga merubah bentuk garis pantai dari Singapura dan disamping itu juga merubah jarak titik-titik batas laut ke daratan Singapura. Menurut data yang diberikan oleh Kompas (2003b), 25 tahun lalu luas Singapura hanyalah 527 kilometer persegi; tahun 1998, luasnya sudah bertambah menjadi 674 kilometer persegi; dan tahun 2010, Singapura menargetkan luas wilayahnya mencapai 834 kilometer persegi.

Meskipun begitu, Prof. Hasyim Jalal sebagai ahli hukum laut Indonesia dan Menteri Luar Negeri RI Hasan Wirayuda menyatakan bahwa koordinat titiktitik batas laut yang telah ditetapkan oleh pemerintah Indonesia dan Singapura pada tahun 1973 tidak akan berubah dengan tenggelamnya pulau Nipah ataupun berubahnya pantai Singapura akibat proses reklamasi [Kompas, 2003b; 2003c].

\subsection{Tuntutan Aplikasi Navigasi Presisi}

Selat Singapura dimana titik-titik batas laut antara Indonesia dan Singapura berada merupakan alur pelayaran internasional yang padat, yang dilalui tidak hanya oleh kapal-kapal kecil tapi juga kapal-kapal berukuran besar.

Di era dimana navigasi presisi dari kapal dimungkinkan dengan menggunakan ECDIS (Electronic Chart Display Information System) [Forbes, 2004] yang dibantu dengan sistem DGPS (Differential GPS) yang dapat memberikan ketelitian pada level 1 meter atau lebih baik dalam datum geodetik WGS84 
[Abidin, 2000], kejelasan dari datum geodetik dari koordinat titik batas menjadi penting.

Dari Tabel 7 sd 10 terlihat bahwa perubahan nilai koordinat geografis titik batas laut RI-Singapura bisa mencapai $25 \mathrm{~m}$ sampai $220 \mathrm{~m}$ tergantung pada asumsi datum geodetik awal yang digunakan untuk koordinat titik batas. Melihat tingkat ketelitian posisi yang dapat diberikan oleh sistem DGPS secara real-time pada level 1 meter atau lebih baik, atau sistem GPS absolut yang hanya pada level 5-10 m, maka kejelasan datum geodetik dari titik-titik batas laut RISingapura memang tidak bisa diabaikan.

Karena ENC (Electronic Navigation Chart) yang digunakan oleh sistem ECDIS, sesuai dengan ketetapan IMO (International Maritime Organization) sebaiknya mempunyai datum WGS84, maka koordinat titik-titik batas laut RISingapura juga sebaiknya ditransformasikan ke sistem WGS84. Untuk dapat mentransformasikan koordinat titik batas tersebut ke sistem WGS84, maka terlebih dahulu datum geodetik awal dari koordinat titik batas yang ditetapkan tahun 1973 tersebut harus diketahui, ditetapkan atau disepakati secara bersama oleh pemerintah Indonesia dan Singapura.

\subsection{Keterkaitan dengan Stasion IGS}

Dalam konteks rekonstruksi ataupun validasi keberadaan titik-titik batas laut, saat ini ada infrastruktur global yang dapat digunakan, yaitu jaringan stasion IGS yang mengamati satelit GPS secara kontinyu dan datanya dapat diakses secara gratis dari internet. Per Desember 2004 ada 381 stasion IGS di seluruh dunia [IGS,2004]. Lokasi dan distribusi dari stasion IGS di seluruh dunia diberikan oleh Gambar 6.

Dalam konteks batas laut Indonesia dan Singapura, stasion NTUS di Singapura dapat digunakan. Koordinat Kartesian ITRF2000 dan koordinat geodetik WGS84 dari stasion ini diberikan pada Tabel 17. Sedangkan posisi stasion NTUS relatif terhadap titik-titik batas ditunjukkan pada Gambar 7.

Tabel 17 Koordinat Station IGS NTUS di Singapura [IGS, 2004].

\begin{tabular}{|l|c|c|r|}
\hline \multicolumn{4}{|c|}{ Koordinat stasion IGS : NTUS (Singapura) } \\
\hline \multicolumn{2}{|c|}{ Koordinat ITRF2000 Epok 1997.0 } & \multicolumn{2}{c|}{ Koordinat Geodetik WGS84 } \\
\hline X (m) & -1508022.690 & $\varphi$ & $1^{\circ} 20^{\prime} 44.88843{ }^{\prime} \mathrm{N}$ \\
\hline Y (m) & 6195576.699 & $\lambda$ & $103^{\circ} 40^{\prime} 47.83905^{\prime \prime} \mathrm{E}$ \\
\hline $\mathbf{Z}(\mathbf{m})$ & 148799.482 & h (m) & 75.412 \\
\hline
\end{tabular}




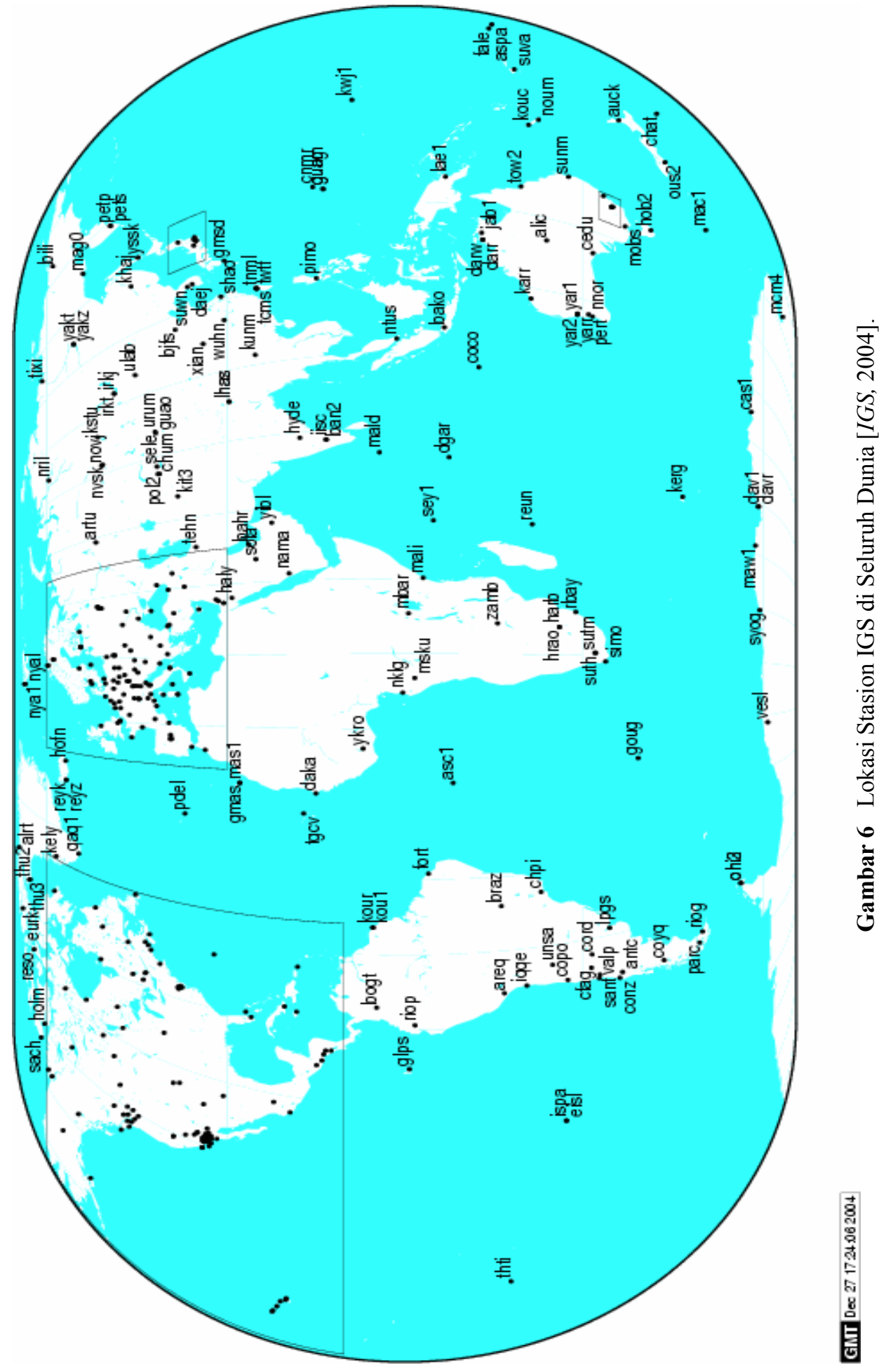




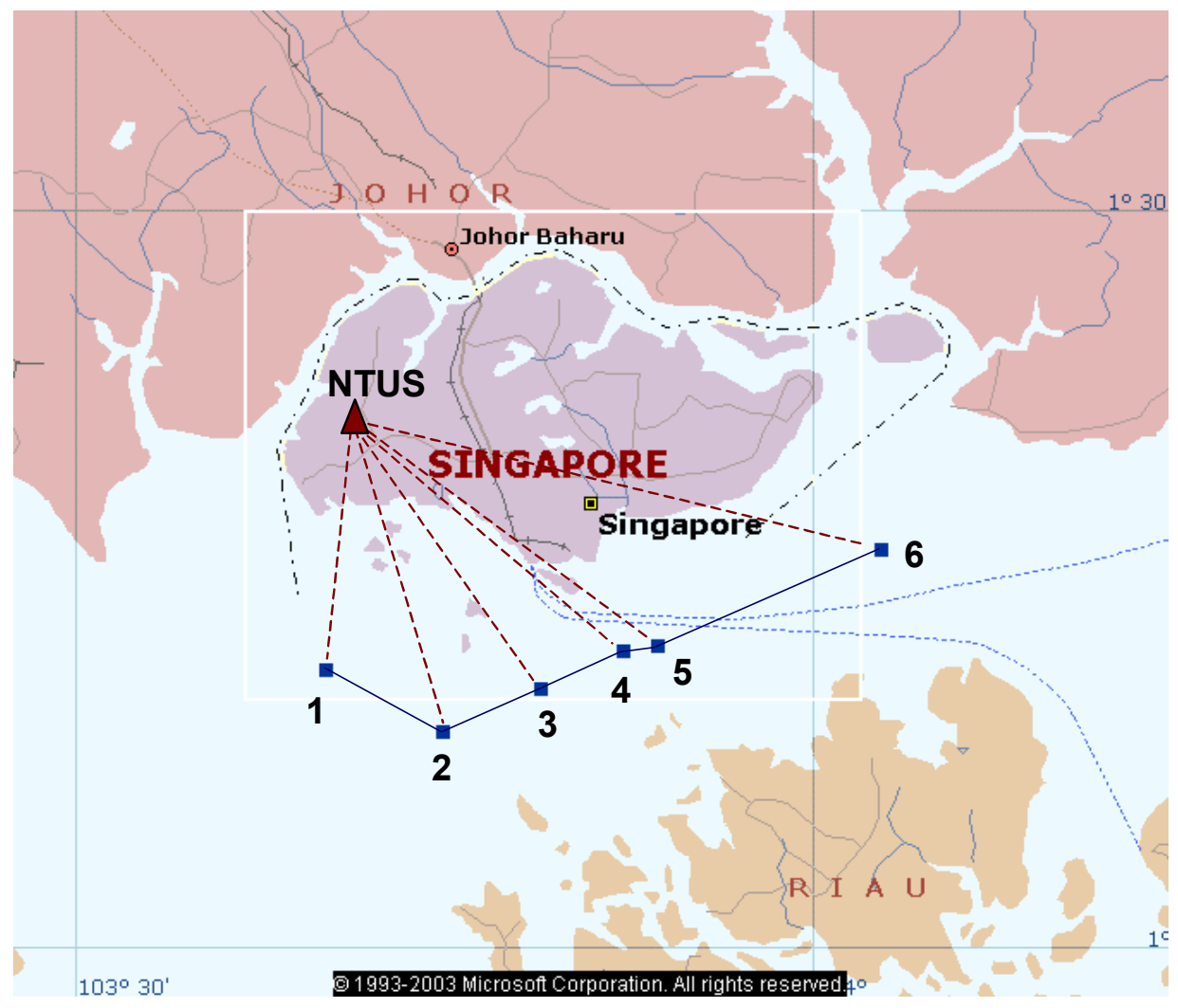

Gambar 7 Posisi stasion NTUS relatif terhadap titik-titik batas laut RISingapura.

Jarak geodetik dari stasion NTUS ke enam titik batas laut RI-Singapura diberikan pada Tabel 18 sebagai fungsi dari datum geodetik awal yang diasumsikan untuk koordinat titik batas. Sedangkan variasi jaraknya diberikan pada Tabel 18. Dari Tabel 18 terlihat bahwa titik batas berjarak sekitar $18 \mathrm{~km}$ sampai $40 \mathrm{~km}$ dari stasion NTUS.

Dari hasil yang diberikan pada Tabel 19 terlihat adanya variasi jarak sampai sekitar $200 \mathrm{~m}$ tergantung pada asumsi dari datum geodetik dari koordinat titik batas yang ditetapkan pada Perjanjian Batas 1973.

Hasil yang diberikan pada Tabel 18 di atas menunjukkan bahwa kejelasan dari datum geodetik titik batas laut RI-Singapura adalah suatu yang penting dan secara teknis tidak bisa diabaikan. 
Tabel 18 Jarak Geodetik antara Station IGS NTUS dan Titik Batas Laut.

\begin{tabular}{|c|c|c|c|c|c|}
\hline \multirow{2}{*}{$\begin{array}{c}\text { Titik } \\
\text { Batas }\end{array}$} & \multicolumn{5}{|c|}{ Jarak Geodetik Titik Batas dari Stasion IGS : NTUS } \\
\cline { 2 - 6 } & $\begin{array}{c}\text { WGS84 } \\
\text { (Perjanjian) }\end{array}$ & $\begin{array}{c}\text { WGS84 } \\
\text { (dari } \\
\text { KERTAU48) }\end{array}$ & $\begin{array}{c}\text { WGS84(dari } \\
\text { KERTAU68) }\end{array}$ & $\begin{array}{c}\text { WGS84(dari } \\
\text { GENUK) }\end{array}$ & $\begin{array}{c}\text { WGS84 (dari } \\
\text { SOUTHASIA) }\end{array}$ \\
\hline $\mathbf{1}$ & 18423.670 & 18439.870 & 18440.630 & 18476.020 & 18449.530 \\
\hline $\mathbf{2}$ & 24762.900 & 24715.200 & 24717.040 & 24879.200 & 24786.370 \\
\hline $\mathbf{3}$ & 23777.590 & 23669.310 & 23671.500 & 23947.880 & 23795.800 \\
\hline $\mathbf{4}$ & 25985.410 & 25839.810 & 25842.300 & 26181.950 & 25998.380 \\
\hline $\mathbf{5}$ & 27094.210 & 26937.440 & 26940.170 & 27297.040 & 27105.090 \\
\hline $\mathbf{6}$ & 40222.530 & 40032.320 & 40034.930 & 40432.040 & 40223.650 \\
\hline
\end{tabular}

Tabel 19 Variasi Jarak Geodetik antara Station IGS NTUS dan Titik Batas Laut.

\begin{tabular}{|c|c|c|c|c|c|}
\hline \multirow[b]{2}{*}{$\begin{array}{l}\text { Titik } \\
\text { Batas }\end{array}$} & \multicolumn{5}{|c|}{ Variasi Geodetik Titik Batas dari Stasion IGS : NTUS } \\
\hline & $\begin{array}{c}\text { WGS84 } \\
\text { (Perjanjian) }\end{array}$ & $\begin{array}{c}\text { WGS84 } \\
\text { (dari } \\
\text { KERTAU48) }\end{array}$ & $\begin{array}{l}\text { WGS84(dari } \\
\text { KERTAU68) }\end{array}$ & $\begin{array}{l}\text { WGS84(dari } \\
\text { GENUK) }\end{array}$ & $\begin{array}{l}\text { WGS84 (dari } \\
\text { SOUTHASIA) }\end{array}$ \\
\hline 1 & 0.00 & 16.20 & 16.96 & 52.35 & 25.86 \\
\hline 2 & 0.00 & -47.70 & -45.86 & 116.30 & 23.47 \\
\hline 3 & 0.00 & -108.28 & -106.09 & 170.29 & 18.21 \\
\hline 4 & 0.00 & -145.60 & -143.11 & 196.54 & 12.97 \\
\hline 5 & 0.00 & -156.77 & -154.04 & 202.83 & 10.88 \\
\hline 6 & 0.00 & -190.21 & -187.60 & 209.51 & 1.12 \\
\hline
\end{tabular}

\section{$5 \quad$ Kesimpulan dan Saran}

Perjanjian batas maritim antara Indonesia dan Singapura tahun 1973 tidak secara eksplisit menyebutkan tentang datum geodetik yang digunakan untuk koordinat titik-titik batas yang dicantumkan dalam perjanjian. Meskipun perjanjian batas maritim antara Indonesia dan Singapura tersebut dilampiri dengan peta; fungsi utama dari peta tersebut nampaknya adalah untuk memberi gambaran tentang lokasi dan konfigurasi dari titik-titik batas yang bersangkutan, dan bukan untuk menginformasikan datum geodetik yang digunakan oleh koordinat titik-titik batas tersebut. Oleh sebab itu dalam perjanjian-perjanjian batas zona maritime lainnya dengan negara-negara tetangga sebaiknya datum geodetik dari koordinat titik-titik batas yang terlibat disebutkan secara eksplisit dalam perjanjian batas yang bersangkutan.

Karena semua koordinat titik garis pangkal (basepoints) Kepulauan Indonesia, sebagaimana ditetapkan dalam Peraturan Pemerintah No. 38 Tahun 2002, mengacu pada datum geodetik WGS84; maka sebaiknya datum geodetik yang digunakan untuk batas maritim Indonesia dengan negara tetangga adalah juga 
datum WGS84. Disamping itu WGS84 adalah datum global yang saat ini banyak digunakan secara internasional, dan juga realisasinya dapat dilakukan secara relatif mudah dan akurat dengan menggunakan teknologi penentuan posisi GPS yang popular dan banyak digunakan orang saat ini.

Berdasarkan sejarah pemanfaatan serta cakupan wilayahnya, ada empat datum geodetik yang dapat dipertimbangkan sebagai datum alternatif untuk koordinat titik batas laut teritorial antara Indonesia dan Singapura yang dicantumkan dalam perjanjian 1973, yaitu datum-datum KERTAU48, KERTAU68, GENUK dan SOUTH ASIA. Kalau dibandingkan terhadap koordinat perjanjian yang dianggap langsung berada dalam datum WGS84, maka penggunaan datum alternatif tersebut akan menggeser garis batas laut Indonesia - Singapura sebesar 25 sampai $200 \mathrm{~m}$ tergantung datum alternatif yang digunakan (lihat Tabel 20 berikut). Pergeseran ini dapat menguntungkan atau merugikan Indonesia.

Tabel 20 Pergeseran Batas RI-Singapura Sebagai Fungsi dari Datum Alternatif yang Diadopsi.

\begin{tabular}{|c|c|c|c|c|}
\hline $\begin{array}{c}\text { Dengan } \\
\text { Negara }\end{array}$ & $\begin{array}{c}\text { Jenis } \\
\text { Batas }\end{array}$ & Datum Alternatif & $\begin{array}{c}\text { Pergeseran Posisi } \\
\text { (Arah ke) }\end{array}$ & $\begin{array}{c}\text { Pihak Yang } \\
\text { Diuntungkan }\end{array}$ \\
\hline \multirow{3}{*}{ Singapura } & \multirow{2}{*}{$\begin{array}{c}\text { Territorial } \\
\text { Sea }\end{array}$} & KERTAU48 & $\begin{array}{c}190-196 \mathrm{~m} \\
\text { (Barat) }\end{array}$ & Indonesia \\
\cline { 3 - 5 } & \cline { 3 - 5 } & KERTAU68 & $\begin{array}{c}188-193 \mathrm{~m} \\
\text { (Barat) }\end{array}$ & Indonesia \\
\cline { 3 - 5 } & & GENUK & $\begin{array}{c}210-215 \mathrm{~m} \\
\text { (Tenggara) }\end{array}$ & Singapore \\
\cline { 3 - 5 } & & SOUTH ASIA & $\begin{array}{c}25-26 \mathrm{~m} \\
\text { (Barat) }\end{array}$ & Indonesia \\
\hline
\end{tabular}

Datum alternatif final yang akan diadopsi serta model dan parameter transformasi yang akan digunakan perlu dibicarakan secara bilateral antara Indonesia dan Singapura, dan sebaiknya mulai disosialisasikan dan dibicarakan sejak saat ini dalam pertemuan-pertemuan teknis menyangkut batas antar kedau negara.

Perlu juga dicatat juga bahwa penanganan dan penyelesaian masalah ketidakjelasan datum geodetik batas maritim antar Indonesia dengan Singapura menjadi lebih sulit dengan adanya beberapa permasalahan yang terkait seperti berikut:

1. tingkat ketelitian koordinat titik batas yang tidak diketahui nilainya karena tidak dinyatakan secara eksplisit dalam perjanjian batas 1973, 
2. tingkat ketelitian dan keandalan peta yang digunakan untuk pengeplotan titik batas dan pengektrasian koordinat titik batas yang umumnya sulit untuk diketahui secara pasti karena tidak dinyatakan secara eksplisit dalam perjanjian batas 1973,

3. mekanisme penentuan koordinat titik batas yang umumnya dilakukan secara kartometris pada peta berskala relatif kecil sehingga menghasilkan tingkat ketelitian koordinat titik batas yang relatif rendah,

4. implementasi metode penetapan lokasi geografis titik batas (e.g. metode sama-jarak) yang umumnya dilakukan pada bidang proyeksi (bidang datar) dan kerap mengabaikan prinsip dan efek geodetik yang terkait,

a. koordinat titik batas umumnya tidak terikat ke kerangka referensi (reference frame) tertentu, melainkan ke obyek-obyek alamiah seperti pulau-pulau terluar atau garis pantai tertentu, yang dengan waktu bisa berubah bentuk atau bahkan hilang,

b. garis pantai dari masing-masing negara mengacu pada sistem-sistem kordinat dan pemetaan yang belum tentu sama, bahkan umumnya berbeda satu sama lainnya, dan

c. adanya perubahan kedudukan horizontal garis pantai Singapura akibat adanya proses reklamasi pantai.

Akhirnya perlu ditekankan di sini bahwa kalau kita mengacu pada Tabel 1, permasalahan datum geodetik batas maritim tidak hanya ada pada batas antara Indonesia dengan Singapura, tapi juga pada batas maritim antara Indonesia dengan negara-negara tetangga lainnya. Oleh karena itu pengkajian masalah datum geodetik juga sebaiknya dilakukan berkaitan dengan batas maritim Indonesia dengan negara-negara tetangga lainnya tersebut. Walaupun perjanjian batas yang sudah diratifikasi antara Indonesia dengan negara tetangga sudah "mengikat" secara hokum, termasuk nilai koordinat titik-titik batas yang telah ditetapkan dalam perjanjian tersebut; namun pengkajian datum geodetik tersebut tetap perlu dilakukan untuk memberikan kepastian geometris bagi lokasi titik-titik batas tersebut di lapangan, yang kerap diperlukan untuk berbagai aplikasi praktis.

\section{Daftar Pustaka}

1. Abidin, H. Z., Penentuan Posisi Dengan GPS dan Aplikasinya, P.T. Pradnya Paramita, Jakarta, Second edition, ISBN 979-408-377-1 (2000), $268 \mathrm{pp}$.

2. DMA (Defense Mapping Agency), Department of Defense World Geodetic System 1984, Its Definition and Relationships with Local Geodetic Systems. DMA Technical Report 8350.2, September (1991). 
3. Forbes, V. L., Indonesia's Maritime Boundaries, A Malaysian Institute of Maritime Affairs Monograph, ISBN 983-9275-00-3, Malaysian Institute of Maritime Affairs, Kuala Lumpur (1995).

4. Forbes, V. L., ECDIS and Potential Legal Implications: Proceeding with Caution, The Hydrographic Journal, No. 111, pp. 1-11 (January 2004).

5. IGS, Internet homepage dari International GPS Service (IGS), Alamat website: http://igscb.jpl.nasa.gov/, (Desember 2004).

6. JUPEM, Geodesy in Malaysia, National Report 2000-2003, A Country Report for the International Union of Geodesy and Geophysics (IUGG) International Association of Geodesy XXIII General Assembly, June 30 July 12, 2003, Sapporo, Japan (2003).

7. Kompas, Pulau Nipah Segera Direklamasi, Harian Umum KOMPAS, Kamis, 20 Februari 2003 (2003a).

8. Kompas, Konsekuensi Penambangan Pasir Laut dan Keberlanjutan Bahari, Harian Umum KOMPAS, Rabu, 05 November 2003 (2003b).

9. Kompas, Hilangnya Pulau Nipah Tidak Mengubah Kesepakatan Batas Laut Indonesia-Singapura. Harian Umum KOMPAS, Kamis, 06 Februari 2003 (2003c).

10. The Geographer, Territorial Sea Boundary: Indonesia-Singapore, Limits in the Seas, No. 60, Department of State, Washington, D. C. 20520, 11 November (1974).

11. The Geographer, Maritime Boundaries of the World, Limits in the Seas, No. 108, Department of State, Washington, D. C. 20520, 30 November (1990).

12. Vincenty, T., Direct and inverse solutions of geodesics on the ellipsoid with application of nested equations, Survey Review, Vol. XXII, No. 176, pp. 83-93, April (1975). 